\title{
Mechanical and Barrier Properties of Potato Protein Isolate-Based Films
}

\author{
David Schäfer 1,2, Matthias Reinelt ${ }^{2}$, Andreas Stäbler ${ }^{2, *}$ and Markus Schmid 1,2 (D) \\ 1 TUM School of Life Sciences Weihenstephan, Technical University of Munich, 85354 Freising, Germany; \\ david.schaefer@ivv.fraunhofer.de (D.S.); markus.schmid@ivv.fraunhofer.de (M.S.) \\ 2 Fraunhofer Institute for Process Engineering and Packaging IVV, 85354 Freising, Germany; \\ matthias.reinelt@ivv.fraunhofer.de \\ * Correspondence: andreas.staebler@ivv.fraunhofer.de; Tel.: +49-8161-491-411
}

Received: 18 December 2017; Accepted: 30 January 2018; Published: 5 February 2018

\begin{abstract}
Potato protein isolate (PPI) was studied as a source for bio-based polymer films. The objective of this study was the determination of the packaging-relevant properties, including the mechanical properties and barrier performance, of casted potato protein films. Furthermore, the films were analyzed for cross-linking properties depending on the plasticizer concentration, and compared with whey protein isolate (WPI)-based films. Swelling tests and water sorption isotherm measurements were performed to determine the degree of swelling, the degree of cross-linking, and the cross-linking density using the Flory-Rehner approach. The effects of different plasticizer types and contents on compatibility with potato protein were studied. Glycerol was the most compatible plasticizer, as it was the only plasticizer providing flexible standalone films in the investigated concentration range after three weeks of storage. Results indicated that increasing glycerol content led to decreasing cross-linking, which correlated in an inversely proportional manner to the swelling behavior. A correlation between cross-linking and functional properties was also reflected in mechanical and barrier characterization. An increasing number of cross-links resulted in higher tensile strength and Young's modulus, whereas elongation was unexpectedly not affected. Similarly, barrier performance was significantly improved with increasing cross-linking. The overall superior functional properties of whey protein-based films were mainly ascribed to their higher percentage of cross-links. This was primarily attributed to a lower total cysteine content of PPI $(1.6 \mathrm{~g} / 16 \mathrm{~g} \cdot \mathrm{N})$ compared to WPI $(2.8 \mathrm{~g} / 16 \mathrm{~g} \cdot \mathrm{N})$, and the significant lower solubility of potato protein isolate in water at pH $7.0(48.1 \%)$, which was half that of whey protein isolate $(96 \%)$. Comparing on an identical glycerol level (66.7\% ( $w / w$ protein)), the performance of potato protein isolate was about $80 \%$ that of whey protein isolate regarding cross-linking, as well as mechanical and barrier properties.
\end{abstract}

Keywords: potato protein isolate; whey protein isolate; plasticizer; cross-linking; oxygen barrier; mechanical performance

\section{Introduction}

Based on the growing environmental concerns of industry and consumers alike, biodegradable and bio-based packaging systems have received increasing interest in recent decades [1]. Among other biopolymers, various proteins from vegetal or animal sources have been investigated as substitutes for synthetic petroleum-based polymers. In particular, soy, wheat gluten, corn zein, and whey have been commonly studied [2-6]. Thereby, the high barrier properties against the oxygen and $\mathrm{CO}_{2}$ of protein-based coatings were of particular interest. However, their low moisture barrier performances and relatively poor mechanical characteristics as compared to fossil-based materials limit their use in packaging applications [2]. In terms of environmental benefits, the use of co-products from industrial processes is of interest for the development of bio-based materials. Potato fruit juice (PFJ), a by-product 
of the industrial potato starch industry. It is released in large quantities, and is mainly used as animal feed or fertilizer, thus providing only low economic value [7]. Therefore, valorizing this by-product into a high value raw material could contribute to developing sustainable value chains of environmental and economical relevance. PFJ contains $30 \%-41 \%$ of proteins in total solids, and is therefore an interesting source for obtaining potato protein isolates (PPI) [8]. The conventional industrial technique for producing PPI is a combination of heat coagulation at temperatures of $75^{\circ} \mathrm{C}$ to $120^{\circ} \mathrm{C}$, and acid precipitation at $\mathrm{pH} 3.5-5.5$, followed by spray drying [9]. This treatment results in high protein yields, and a low price of $1.4 € / \mathrm{kg}$ to $1.5 € / \mathrm{kg}$ [9]. However, it also often leads to an extensive loss of functional properties due to protein denaturation [7]. In order to maintain the functionality of the proteins, other extraction techniques have been investigated, including metal salts $\left(\mathrm{FeCl}_{3}, \mathrm{ZnCl}_{2}, \mathrm{MnCl}_{2}\right)$ [7,10], ethanol [7], membrane separation (especially ultrafiltration) [8,11], ion-exchange chromatography [12] or expanded bed adsorption (EBA) chromatography [11,13].

Compared to proteins from other cereal and vegetable sources, potato proteins are regarded to be of high nutritional quality, as they contain a balanced amino acid composition, and moreover, a high percentage of lysine $(\sim 8 \%)$ [14], which is often deficient in these crops [7]. Along with their health-promoting qualities, potato proteins also exhibit good functional properties, such as high foaming [15] and emulsifying capacities [16].

Potato proteins are commonly classified into three groups: patatin $(\sim 40 \%)$, protease inhibitors $(20 \%-30 \%)$, and other high molecular weight proteins $(20 \%-30 \%)$ [17]. The patatin fraction comprises a family of glycoproteins existing as an 88-kDa dimer consisting of two $40 \mathrm{kDa}$ to $43 \mathrm{kDa}$ isoforms [12,17]. In contrast, protease inhibitors are a distinctly heterogeneous group of proteins, with molecular weights ranging from $4.3 \mathrm{kDa}$ to $25 \mathrm{kDa}$ [17] and solubility through a wide $\mathrm{pH}$ range, whereas patatin has its solubility minimum at $\mathrm{pH} 4.5$ [18]. Regarding the preparation of film-forming solutions for coating applications, a $\mathrm{pH}>7$ therefore provides a high solubility for all of the potato protein fractions, thus ensuring stable protein dispersion and good network formation as a consequence $[2,10]$.

For biopolymer processing, commonly, both wet-i.e., film casting or the coating of aqueous protein solutions-as well as dry processing technologies, including extrusion, compression, and injection molding, are employed [2]. In both methodologies, the formation of protein films is based on chemical or thermal denaturation during processing. During denaturation, the proteins' molecular structure unfolds, thus resulting in the exposure of initially buried functional groups and sections. These are then capable of forming new intermolecular chain-to-chain interactions, such as disulphide and hydrogen bonds $[9,19]$. With increasing protein-protein interactions, the mechanical strength and barrier properties of the polymer are enhanced [20]. However, in order to improve processability and durability, as well as alter the properties of the required final structure, plasticizers (e.g., glycerol) have to be applied as a formulation constituent [2]. Since various proteins have demonstrated appropriate oxygen and $\mathrm{CO}_{2}$ barrier performances, protein-based materials are primarily of interest as gas barrier films in packaging systems. However, their mechanical properties are mostly inferior competitors with fossil-based polymers.

The functional properties of films based on proteins from different sources have been analyzed in several studies. However, information about the use of potato protein as a source for bioplastic materials is rare. The objective of the present study was to investigate the suitability of potato protein isolate as a new source for bio-based films with regard to mechanical and barrier performance. Furthermore, this study offers a brief overview of the compatibility of potato protein with different commonly used plasticizers in terms of film-forming properties. It also aimed to determine the cross-linking parameters of the protein films, depending on the plasticizer concentration, and relate these parameters to structure-dependent properties, including oxygen and water vapor permeation, as well as mechanical properties. For this, cross-linking properties were investigated with swelling tests using the Flory-Rehner approach and water sorption isotherm measurements.

Test samples were produced using a process developed for whey protein isolate-based films whose capability of a high oxygen barrier was shown in previous studies [21,22]. To the authors' knowledge, 
no fundamental investigations of the barrier and mechanical properties of potato protein-based films have been carried out in previous studies.

\section{Materials and Methods}

\subsection{Materials}

Potato protein isolate (PPI) $(91.3 \%$ protein dry basis) was produced at Fraunhofer IVV (Freising, Germany) via ultra and diafiltration from potato fruit juice provided by Südstärke GmbH (Schrobenhausen, Germany). Whey protein isolate (WPI) (BiPro, min. 95.0\% protein dry basis) was obtained from Davisco Foods International Inc. (Le Sueur, MN, USA). Glycerol and sorbitol were purchased from Th. Geyer GmbH \& Co., KG (Renningen, Germany). Ethylene glycol, propylene glycol, and polyethylene glycol 400 were obtained from Sigma-Aldrich Chemie GmbH (Steinheim, Germany). Deionized water was supplied by Fraunhofer IVV.

\subsection{Solution Preparation}

The whey and the potato protein-based formulations were produced following the method developed by McHugh et al. [23] and Schmid et al. [21]. Aqueous solutions (pH 7) of deionized water and PPI $(5 \% w / w)$ resp. WPI $(10 \% w / w)$ were homogenized using an electric stirrer (Thermomix 31-1, Vorwerk Deutschland Stiftung \& Co., KG, Wuppertal, Germany) at $23^{\circ} \mathrm{C}$ for $30 \mathrm{~min}$ at $200 \mathrm{rpm}$. Then, the solutions were heated at $90^{\circ} \mathrm{C}$ for $30 \mathrm{~min}$, and continuously stirred (200 rpm) until protein denaturation was completed, as published by Schmid [22]. After degassing in an ultrasonic bath (DT 514H, Bandelin electronic GmbH \& Co., KG, Berlin, Germany) at $37 \mathrm{kHz}$ and cooling down to room temperature, the respective amount of plasticizer ( $w / w$ protein) was added to the aqueous solutions. This was then stirred for an additional $30 \mathrm{~min}$ with the Thermomix at $200 \mathrm{rpm}$. Finally, the solutions were filled into laboratory bottles, and treated again in an ultrasonic bath for $15 \mathrm{~min}$ and $37 \mathrm{kHz}$ to remove air bubbles.

The plasticizers studied and the respective molecular weight $\left(M_{\mathrm{W}}\right)$, formula, and percentage of the hydrophilic groups are shown in Table 1.

Table 1. Selected plasticizers for study and characteristic properties.

\begin{tabular}{cccc}
\hline Plasticizer Type & $\boldsymbol{M}_{\mathbf{W}}(\mathbf{g} / \mathbf{m o l})$ & Formula & Hydrophilic Groups (\%) \\
\hline Ethylene glycol (EG) & 62 & $\mathrm{C}_{2} \mathrm{H}_{6} \mathrm{O}_{2}$ & 54.8 \\
Propylene glycol (PG) & 76 & $\mathrm{C}_{3} \mathrm{H}_{8} \mathrm{O}_{2}$ & 44.7 \\
Glycerol (Gly) & 92 & $\mathrm{C}_{3} \mathrm{H}_{8} \mathrm{O}_{3}$ & 55.4 \\
Sorbitol (Sor) & 182 & $\mathrm{C}_{6} \mathrm{H}_{14} \mathrm{O}_{6}$ & 56.0 \\
Polyethylene glycol (PEG) & 400 & $\mathrm{H}\left(\mathrm{OCH}_{2}-\mathrm{CH}_{2}\right)_{8} \mathrm{OH}$ & 36.5 \\
\hline
\end{tabular}

\subsection{Cast Films}

Cast films with a target dry film thickness of $200 \mu \mathrm{m}$ were produced in petri dishes using the denatured protein solutions. The amount of solution needed per film was calculated as a function of the respective dry matter content and a presumed suspension density of $1.1 \mathrm{~g} / \mathrm{cm}^{3}$, as follows:

$$
m_{\text {sus }}=\left(l_{\mathrm{f}} \times w_{\mathrm{f}} \times\left(\frac{d f t}{d m c}\right) \times 100 \%\right) \times \rho_{\text {sus }}
$$

where $l_{\mathrm{f}}$ and $w_{\mathrm{f}}$ are length and width of the film $(\mathrm{cm}), d f t$ is the target dry film thickness $(\mathrm{cm}), d m c$ is the dry matter content of the suspension $(\%)$, and $\rho_{\text {sus }}$ is the suspension density $\left(\mathrm{g} / \mathrm{cm}^{3}\right)$. The films were dried in a climate chamber at $23{ }^{\circ} \mathrm{C}$ and $50 \% \mathrm{RH}$ (relative humidity) until a state of equilibrium was evidenced by weight constancy. 


\subsection{Residual Moisture Determination}

The determination of residual moisture content was carried out using a moisture analyzer (MA 100, Sartorius AG, Goettingen, Germany). The sample was dried at $105^{\circ} \mathrm{C}$ until a mass constancy (less than $1 \mathrm{mg}$ per $300 \mathrm{~s}$ ) was reached. The water content was given as percentage of weight loss. For each sample, a threefold determination was performed.

\subsection{Protein Solubility}

Protein solubility measurement was carried out by determining the nitrogen solubility index (NSI) according to the AOCS Official Method Ba 11-65 [24] and AACC method 46-23 [25]. For preparation, $1.5 \mathrm{~g}$ of the protein sample were mixed with $40 \mathrm{~mL}$ of $\mathrm{NaCl}$ solution, as well as a defoamer, and stirred until the product was dispersed. The $\mathrm{pH}$ value was adjusted to $\mathrm{pH} 7.0$ using $0.1 \mathrm{M} \mathrm{NaOH}$, and held constant for $1 \mathrm{~h}$. The solution was then mixed in a 50-mL volumetric flask with $0.1 \mathrm{M}$ $\mathrm{NaCl}$ solution. Then, $20 \mathrm{~mL}$ of this solution was centrifuged for $15 \mathrm{~min}$ at $20,000 \mathrm{~g}$ and $15{ }^{\circ} \mathrm{C}$ with a Sigma $3 \mathrm{~K}$ centrifuge (Sigma Laborzentrifugen $\mathrm{GmbH}$, Osterode am Harz, Germany). The supernatant was filtered through a Whatman No.1 filter (GE Healthcare Europe GmbH, Freiburg, Germany), and the protein content was then determined with a nitrogen analyzer (TruMAC N, Leco Instrumente, Mönchengladbach, Germany) using the method by Dumas [24]. The amount of dissolved protein is expressed as percentage by weight. Two determinations per sample were performed.

\subsection{Thickness Measurement}

For mechanical and barrier characterizations, thickness measurements of the films are necessary. Since cast films are produced on a laboratory scale, the thickness of each film has to be measured with a precision thickness gauge FT3 (Hanatek, St. Leonards-on-Sea, UK). An arithmetic average value at five random positions of the film area is determined at $23{ }^{\circ} \mathrm{C}$ and $50 \% \mathrm{RH}$.

\subsection{Determination of the Degree of Swelling, Degree of Cross-Linking and the Cross-Linking Density}

To determine the degree of swelling (DoS), the degree of cross-linking (DoC), and the cross-linking density (CLD), swelling tests were carried out following the methods described by Schmid et al. [26] and Schmid et al. [27]. The tests were performed according to the DIN EN ISO 175:2000 [28]. The DoS (\%) was determined by a gravimetric method, and is defined as the percentage change in weight after removal from the swelling medium. For an optimal statistical evaluation, a fivefold determination was performed with samples of $50 \mathrm{~mm} \times 50 \mathrm{~mm}$ size. To evaluate quantitative information about the cross-linking properties of potato protein-based films, the DoC and CLD were calculated.

The DoC (\%) is defined as [26]:

$$
\mathrm{DoC}=\frac{\overline{M_{0}}}{M_{\mathrm{C}}}
$$

where $\overline{M_{0}}(\mathrm{~g} / \mathrm{mol})$ is the molecular weight of the mean amino acid of PPI, and $M_{\mathrm{C}}$ is the average molecular weight of the polymer between cross-links $(\mathrm{g} / \mathrm{mol})$. The used $\overline{M_{0}}$ of PPI is $133.2 \mathrm{~g} / \mathrm{mol}$ based on a theoretical calculation [29], and $\overline{M_{0}}$ of WPI is $123.3 \mathrm{~g} / \mathrm{mol}$ [26].

The CLD $(\mathrm{mol} / \mathrm{g})$ is the inverse of the average molecular weight of the polymer between cross-links [30].

$M_{C}$ was determined by swelling tests using the Flory-Rehner equation. The density of the PPI films of $1.30 \mathrm{~g} / \mathrm{cm}^{3}$ was gravimetrically calculated. For the calculation of $M_{C}$, the Flory-Huggins interaction parameter $\chi$ is required, which was determined by water sorption isotherm measurements. All of the applied measurements and data evaluations were performed according to the procedure by Schmid et al. [26] and Schmid et al. [27], with 22-mm diameter samples and a maximum measurement period of $3000 \mathrm{~min}$. A threefold determination was carried out per sample. 


\subsection{Determination of Mechanical Properties}

Mechanical properties such as Young's modulus (E), tensile strength (TS), and elongation at break $\left(\varepsilon_{\mathrm{b}}\right)$ were measured using a tensile testing machine Z005 (Allround Line) from Zwick GmbH \& Co., KG, Ulm, Germany following the DIN EN ISO 527-1 method [31]. For tensile tests, strips of $15 \mathrm{~mm}$ width and $70 \mathrm{~mm}$ length per specimen were prepared and clamped in the testing machine, with a clamping length of $50 \mathrm{~mm}$. The test speed was $50 \mathrm{~mm} / \mathrm{min}$, with a pre-load of $0.3 \mathrm{~N}$ and a load shut-off at $95 \%$. A fivefold determination for each sample was performed at $23{ }^{\circ} \mathrm{C}$ and $50 \% \mathrm{RH}$.

\subsection{Determination of Barrier Properties}

The water vapor transmission rate (WVTR) was determined with a gravimetric method at $23^{\circ} \mathrm{C}$ according to DIN 53122-1 [32]. The initial weight of the test cups was measured using an analytical balance $\mathrm{H} 315$ (Mettler-Toledo $\mathrm{GmbH}$, Columbus, $\mathrm{OH}, \mathrm{USA}$ ), and then stored at $23^{\circ} \mathrm{C}$ and $50 \% \mathrm{RH}$ in a climate chamber from Binder $\mathrm{GmbH}$ (Tuttlingen, $\mathrm{GmbH}$ ). Samples were weighed twice a day until attaining a constant weight. A fourfold determination was carried out for each sample. The water vapor transmission rate $\left(\mathrm{g} / \mathrm{m}^{2} \cdot \mathrm{d}\right)$ was calculated using the following equation:

$$
\mathrm{WVTR}=\frac{24}{t} \times \frac{\Delta m}{A} \times 10^{4}
$$

where $t$ is the time between two weight measurements (h), $\Delta m$ is the weight difference between two weight measurements $(\mathrm{g})$, and $A$ is the sample area $\left(\mathrm{cm}^{2}\right)$.

Oxygen permeability (OP) was measured with an oxygen-specific carrier gas method using an Ox-Tran Twin Oxygen Permeation Measuring Machine (MOCON Inc., Minneapolis, MN, USA) according to DIN 53380-3 [33], at testing conditions of $23^{\circ} \mathrm{C}$ and $50 \%$ RH. For each specimen, a twofold determination was performed, and the OP values were given in the unit $\left(\mathrm{cm}^{3} / \mathrm{m}^{2} \cdot \mathrm{d} \cdot \mathrm{bar}\right)$. For better comparability of different polymeric materials independent of the thickness, the permeability $Q$ can be standardized to a film thickness of $100 \mu \mathrm{m}$ [27]:

$$
Q_{100}=Q \times \frac{d}{100}
$$

\subsection{Statistical Evaluation}

Statistical evaluations were performed with the software Visual-XSel ${ }^{\circledR}$ Version 13.0 Multivar (CRGRAPH GbR, Starnberg, Germany). All of the measured data were checked on normal distribution depending on the sample size, by either the Kolmogorov-Smirnov test (sample size $\leq 4$ ) or the Anderson-Darling normality test (sample size $\geq 5$ ), with a significance value $\alpha$ of 0.05 . The Hampel test for outliers was performed to detect and eliminate outliers in the data set that were not normally distributed ( $p$-value: 0.05 ). For the comparison of sample sets, a multi-T test was carried out using a significance value of 0.05 [34]. Statistical significant differences between sample sets are marked by different letters in the figures and tables.

\section{Results and Discussion}

Film-forming properties, as well as the mechanical and barrier performances of biopolymers, are generally associated with the chemical and physical composition and structure of the polymers, and additionally the nature and concentration of the used plasticizer. As a prerequisite for the formation of flexible coherent films, plasticizers must be compatible with the polymer and permanent in the polymer matrix to achieve the requested film properties [35].

In this study, various plasticizers have been investigated based on their compatibility with a wide range of proteins in order to reduce the brittleness of protein-based films. They represent different chemical constitutions, sizes, and shapes; providing information on the impacts of these factors on interactions between plasticizer and potato protein thus also informs film-forming properties. 


\subsection{Plasticizer Effect and Compatibility}

Characteristic properties of the plasticizer are of particular importance regarding their ability to interfere with protein chain-to-chain interactions, but they are also important for binding water to the polymer matrix, since water acts as an effective plasticizer in edible films [36,37]. Cast PPI-based films with different plasticizers and plasticizer concentrations ranging from $100 \%$ to $200 \%$ ( $w / w$ protein) were prepared as described in Sections 2.2 and 2.3. Table 2 displays the different cast films obtained after a drying time of three weeks. All of the plasticized PPI films were dark brown and opaque. However, it was quite noticeable that, depending on the type of plasticizer and its concentration applied, the resulting films ranged from broken structures over brittle films with defects to homogeneous closed ones. This indicates that each plasticizer showed a different plasticization effect in the selected plasticizer concentration range.

Table 2. Dried cast films with different plasticizers and plasticizer contents from $100 \%$ to $200 \%$ ( $w / w$ protein) after 21 days at $23{ }^{\circ} \mathrm{C}$ and $50 \% \mathrm{RH}$. The amount of plasticizer is referred to the pure protein content $(w / w$ protein).

\begin{tabular}{|c|c|c|c|c|c|}
\hline \multirow{2}{*}{ Plasticizer } & \multicolumn{5}{|c|}{ Plasticizer ( $w / w$ Protein) } \\
\hline & $100 \%$ & $125 \%$ & $150 \%$ & $175 \%$ & $200 \%$ \\
\hline Ethylene glyco & & & & & \\
\hline Propylene glyc & & & & & \\
\hline Glycerol & & & & & \\
\hline Sorbitol & & & & & \\
\hline $\begin{array}{l}\text { Polyethylene } \\
\text { glycol } 400\end{array}$ & & & & & \\
\hline
\end{tabular}

\subsubsection{Effects of Glycerol, Sorbitol, and PEG 400}

In general, almost all of the plasticizers studied seemed to possess a poor compatibility with potato protein, since most films tended to form brittle films, with a large number of cracks within 
the plasticizer concentration range investigated. A sufficient plasticizing effect was observed at all concentrations for only glycerol. Despite their difference in hydrophilic groups and molecular weight, the films obtained with sorbitol and polyethylene glycol (PEG) 400 showed a similar plasticizing behavior. At low concentrations, the films had large cracks, but film-forming properties improved with increasing plasticizer content, resulting in smaller and fewer defects. However, the films produced with PEG 400 and sorbitol had a very soft, almost creamy consistency above a plasticizer content of $175 \%$ ( $w / w$ protein). Therefore, it was impossible to remove these films from the Petri dish. In addition, sorbitol tended to crystallize at several spots on the surface of the films after about two weeks at ambient drying conditions. This is because sorbitol is present in its solid form at these conditions. Therefore, with increasing sorbitol content, the extent of crystallization also increased, but had no counteractive effect on the film softness.

Glycerol and sorbitol show similarities in straight-chain structure, molecular composition, and the percentage of hydrophilic groups, with the latter being crucial for the formation of hydrogen bonding with potato protein. However, glycerol possessed a significant higher plasticizer efficiency than sorbitol when comparing equivalent mass contents. This might be due to the lower $M_{\mathrm{W}}$ of glycerol. This could facilitate its incorporation into the polymer matrix, and thus its ability to impair hydrogen bonds between polypeptide chains. Furthermore, by decreasing the $M_{\mathrm{W}}$ of the plasticizers, the molar content in the film is increased when the weight-to-weight ratio is kept constant. This enhances the plasticizing effect $[20,35,37]$. As further explained below, sorbitol's lack of plasticizing efficacy could additionally be attributed to its lower water-binding capacity and hygroscopicity [38]. The high plasticization effect of glycerol at equivalent mass content was also observed for $\beta$-lactoglobulin films [37], whey protein films [20], fish myofibrillar protein-based films [39], and peanut protein films [40], among others.

As shown in Figure 1, glycerol plasticized films contain significantly higher equilibrium moisture contents $(p<0.05)$ than films produced with other plasticizers. This could be an additional explanation for the superior plasticizing efficiency of glycerol. The distinct ability to attract water to a polymer system and retain it at equilibrium state is resulting in more flexible films. This is because water acts as a plasticizer itself $[20,41]$. With increasing glycerol concentration, the moisture content in the film was increasing linearly $\left(R^{2}=0.964\right)$. However, for sorbitol films, a similar linear correlation was only observed up to a plasticizer content of $150 \%$ ( $w / w$ protein). Therefore, it can be assumed that sorbitol is not able to incorporate additional water molecules into the polymer matrix by further increasing the plasticizer content. This could be explained by a protein matrix saturation and plasticizer exclusion, as similarly suspected by Ramos et al. [42] for glycerol plasticized whey protein films.

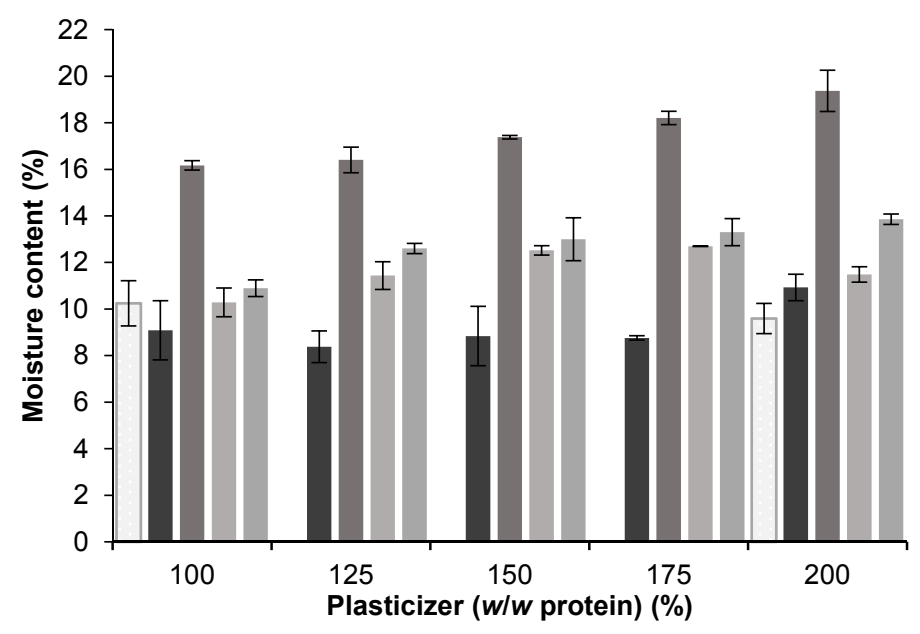

Figure 1. Equilibrium moisture content of the cast films after three weeks at $23{ }^{\circ} \mathrm{C}$ and $50 \% \mathrm{RH}$ with different plasticizer concentrations $(100 \%-200 \%$ ( $w / w$ protein $))$ in the following order: EG, PG, glycerol, sorbitol and PEG 400. Error bars show standard deviation. 
The hypothesis of a negative impact of a high molecular weight on plasticizing properties has been frequently described in the literature [35-37]. However, it was assumed that the higher $M_{W}$ of PEG 400 is compensated by its chemical structure, resulting in a sorbitol-like plasticizing effect. Sothornvit and Krochta [35] supposed that this behavior is based on the specific arrangement of oxygen atoms in PEG 400. In the elongated PEG 400 molecular chain, one oxygen atom alternates with two carbon atoms. Thereby, the space available for the formation of hydrogen bonds with polypeptide chains might be higher in contrast to sorbitol, which contains hydroxyl groups attached to molecule backbone on adjacent carbon atoms.

\subsubsection{Effects of EG and PG}

The use of propylene glycol (PG) showed the lowest impact with respect to film flexibility. Independent of the plasticizer concentration, the films cracked after only seven days' storage. Unlike the other plasticizers studied (except ethylene glycol, or EG), an increasing PG content did furthermore not result in any improvement in film-forming properties. This is most likely due to the lower polarity of PG compared with other plasticizers. Therefore, interactions with the polar protein sites were restricted. This resulted in a low ability to form flexible coherent films in the studied concentration range. This is despite the low small molecular weight and high hygroscopicity of PG [38]. This is most likely due to its high vapor pressure at $20^{\circ} \mathrm{C}$, exceeding the one of glycerol [43]. This property was causing a low permanence in the casted film. Similar results were reported by Sothornvit and Krochta [37] and Orliac et al. [44] for PG-plasticized $\beta$-lactoglobulin films and sunflower protein films, respectively.

An analogical drying behavior was observed for EG-plasticized films. Even though they showed a closed structure in the initial phase of drying, cracks and defects were visible after three weeks of storage. The vapor pressure of EG is lower than that of PG [43].Therefore, EG was retained in the film longer than PG, thus resulting in a prolonged plasticizing effect. Moreover, the lower polarity of EG compared to glycerol could be an additional reason for a minor plasticizing efficiency. This result was also confirmed by Viroben et al. [45]. In his study, he described a high loss of EG in pea protein films during drying, presumably due to weaker interactions with the protein chains. Furthermore, Viroben et al. suggested that the increased occurrence of intermolecular protein-protein interactions due to the continuous loss of plasticizer was causing film brittleness and cracks [45]. A correlation of plasticizer concentration and humidity was not identifiable (see Figure 1). This is indicating a complete release of EG and PG from the protein films, and thus, the plasticizer did not affect the equilibrium moisture content (not significant different $(p<0.05)$ ).

Various authors (Cuq, Gontard, Cuq and Guilbert [39]; Sothornvit and Krochta [37]) compared fish myofibrillar protein-based and $\beta$-lactoglobulin-based films using different plasticizers applied at same mass concentrations in film-forming solutions. They concluded that lower molecular weight plasticizers are more effective in film plasticization, due to the higher molar concentration of the additives. However, these studies also stated that the theory of the higher plasticizing efficiency of lower $M_{\mathrm{W}}$ plasticizers is not generally applicable. Despite its larger molecular weight, glycerol has a higher plasticizing effect than PG and EG. These results were confirmed by Viroben, Barbot, Mouloungui and Guéguen [45], and Vanin et al. [46]. In their studies, the plasticizing effect of glycerol exceeded that of EG when applied in pea protein-based resp. gelatin-based films. According to Donhowe and Fennema [47], this theory of chain length is only applicable when the molecular weight of the plasticizers is considerably different. When comparing the plasticizing effects of EG, PG, and glycerol, the number and position of the reactive hydroxyl groups $(-\mathrm{OH})$ appear to be an important factor demonstrating the impact of the chemical structure on plasticizer-polypeptide interactions. 


\subsection{Intermolecular Characteristics}

\subsubsection{Cross-Linking Density and Degree of Cross-Linking}

Figure 2 shows the CLD and DoC values of PPI-based cast films depending on the glycerol concentration ( $w / w$ protein) in comparison to a WPI-based reference cast film. All of the PPI-based samples showed significantly $(p<0.05)$ lower CLD and DoC values compared to the WPI-based standard, with a nearly linear decrease with increasing glycerol content.

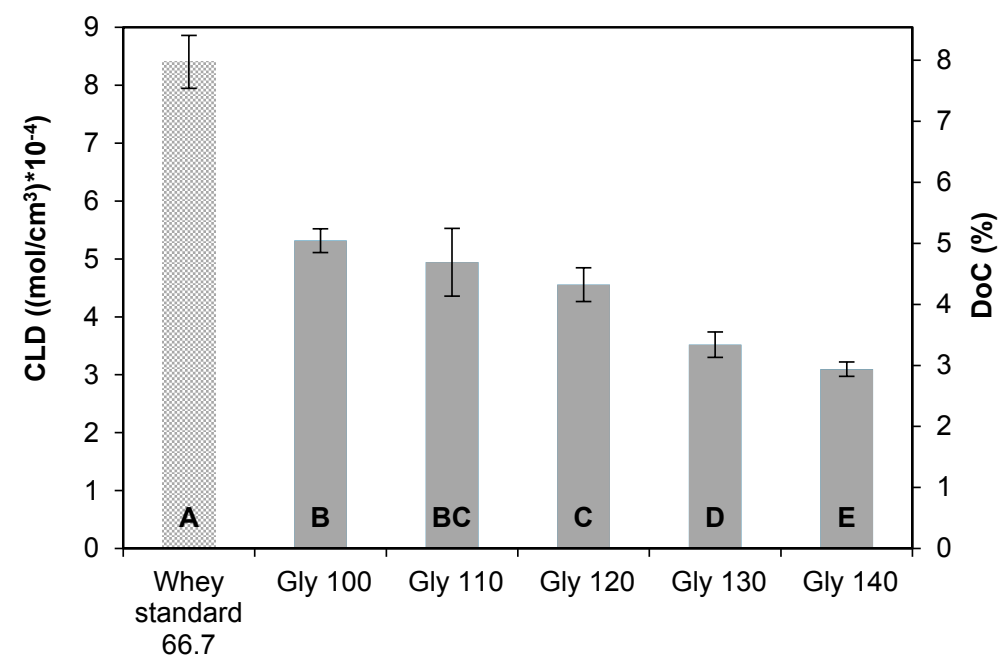

Figure 2. Cross-linking density (CLD) and the degree of cross-linking (DoC) of whey protein isolate (WPI)-based cast film (standard) and potato protein isolate (PPI)-based cast films as a function of glycerol (Gly) concentration ( $w / w$ protein). Columns with different letters are significantly different $(p<0.05)$. Error bars denote standard deviation.

The decline of cross-linking of the PPI-based films with increasing glycerol concentration was ascribed to the ability of plasticizers to reduce intermolecular interactions between polymer chains and increase free volume and chain mobility [48]. Furthermore, the increasing moisture content of the films with increasing glycerol concentration contributes to an increase in the free volume, due to the plasticizing property of water.

Since PPI-based films with a glycerol content from $70 \%(w / w$ protein) showed a brittle cracked structure, a direct comparison with a $66.7 \%$ ( $w / w$ protein) glycerol-containing WPI film was not feasible. Therefore, a valuation by means of the linear course of the measured values was made. Comparing a PPI-based film with an identical glycerol content as the whey protein standard (66.7\% ( $w / w$ protein)), the DoC and CLD is about $80 \%$ that of the WPI standard film. Since DoC and CLD only represent the percentage of covalent disulphide bonds, one major reason for that might be the lower total cysteine content of PPI, which is $1.6 \mathrm{~g} / 16 \mathrm{~g} \cdot \mathrm{N}$ [8], whereas for WPI it is $2.8 \mathrm{~g} / 16 \mathrm{~g} \cdot \mathrm{N}$ [19]. In addition, patatin, the major potato protein fraction, contains only one thiol group among 362 amino acids [14], whereas the main whey fraction $\beta$-lactoglobulin possesses five thiol groups among 162 amino acids [49]. The statistical probability of forming disulphide bonds is thus considerably lower for PPI. Moreover, the aggregation behavior of patatin may play a role. Pots [14] detected a clearly different aggregation mechanism of patatin compared to $\beta$-lactoglobulin, and concluded that the formation of disulphide bonds via thiol-thiol reactions is not the determining initial step for the aggregation. He rather suggests other interactions, such as hydrogen bonds or hydrophobic interactions, to be more determinant. Disulphide bonding may only be achievable when the molecules are in a particular orientation close to each other, or already high molecular aggregates exist [14]. Creusot et al. [50] also reported an unusually high exposed hydrophobicity of patatin during the unfolding of the tertiary structure. 
Another reason for the lower cross-linking of PPI-based films might be the significant lower solubility of PPI, which was $48.1 \%$ at $\mathrm{pH} 7.0$, whereas it was twice as high for WPI $(96.0 \%)$. Waglay, Karboune, and Alli [7] demonstrated that the solubility of potato protein isolates is highly dependent on the protein extraction technique. In general, the literature reports protein solubilities of $50 \%$ to $85 \%$ when gentle recovery processes are applied [13,51]. The solubility of potato proteins is an important property, as it contributes to the unfolding of the protein tertiary structure, which enables interactions with both the solvent and other protein molecules. This conformational change leads to the exposure of hydrophobic parts and initial buried free reactive groups that need to be accessible for the formation of new intermolecular interactions. In contrast, undissolved protein molecules show a significantly higher thermal stability [2]. Since the solubility in water is essential for potato protein denaturation to occur, poor protein dispersion leads to a lower proportion of intermolecular interactions between the protein chains during heating, which results in limited network formation, as observed by several authors [52,53]. Besides, other important factors, such as protein structure, polymer orientation and solvent-polymer interaction parameters must be considered when characterizing the cross-linking properties of biopolymers [54]. According to the author's knowledge, no comparable studies have been published dealing with the cross-linking properties of potato protein-based cast films, up until now. However, the results by Ahmed, Nizami, Raza, and Mahmood [30] for natural rubber, which is also linked via disulfide bonds and possesses similar mechanical behavior, may serve as a suitable reference point. According to these authors, the CLD of natural rubber of $2.0 \times 10^{-4} \mathrm{~mol} / \mathrm{cm}^{3}$ is significantly lower compared to the CLD of both the whey protein standard, with $8.4 \times 10^{-4} \mathrm{~mol} / \mathrm{cm}^{3}$, and the PPI-based films from 5.3 to $3.1 \times 10^{-4} \mathrm{~mol} / \mathrm{cm}^{3}$. The high deviation from this literature value may be based on various influencing factors during production and analysis processes. Thereby, the decisive factor is the volume fraction of the polymer in the swollen gel, which is determined by swelling tests. It has a great influence on the average molecular weight of the polymer between cross-links $\left(M_{\mathrm{c}}\right)$, and therefore on the DoC and CLD.

\subsubsection{Degree of Swelling}

By absorbing a solvent, the distance between cross-linked polymer chains increases due to swelling. Against that, these covalent forces prevent the polymer film from unlimited dissolving, and thus enable it to maintain a coherent structure.

The DoS (see Figure 3) showed an inversely proportional correlation to the DoC and CLD. The WPI sample has the lowest DoS value of about $300 \%$, while the DoS values of PPI-based films are significantly $(p<0.05)$ higher, increasing linear from $560 \%$ to $920 \%$. This behavior is coincident with the findings of Schmidt et al. [55] and Schmid et al. [56], who concluded that an increasing amount of cross-linking within the polymeric matrix results in a declining swelling capacity. This effect is ascribed to the reduced free volume between the polymer chains with increasing network formation, and thus, less available space to incorporate water. Moreover, the mobility of the polymer chains decreases [48]. The capability of glycerol to bind water into the polymeric matrix could be neglected since previous studies proved that glycerol, which is bound to the protein only by weak hydrogen bonds, is almost completely removed from the films during the swelling process [9]. 


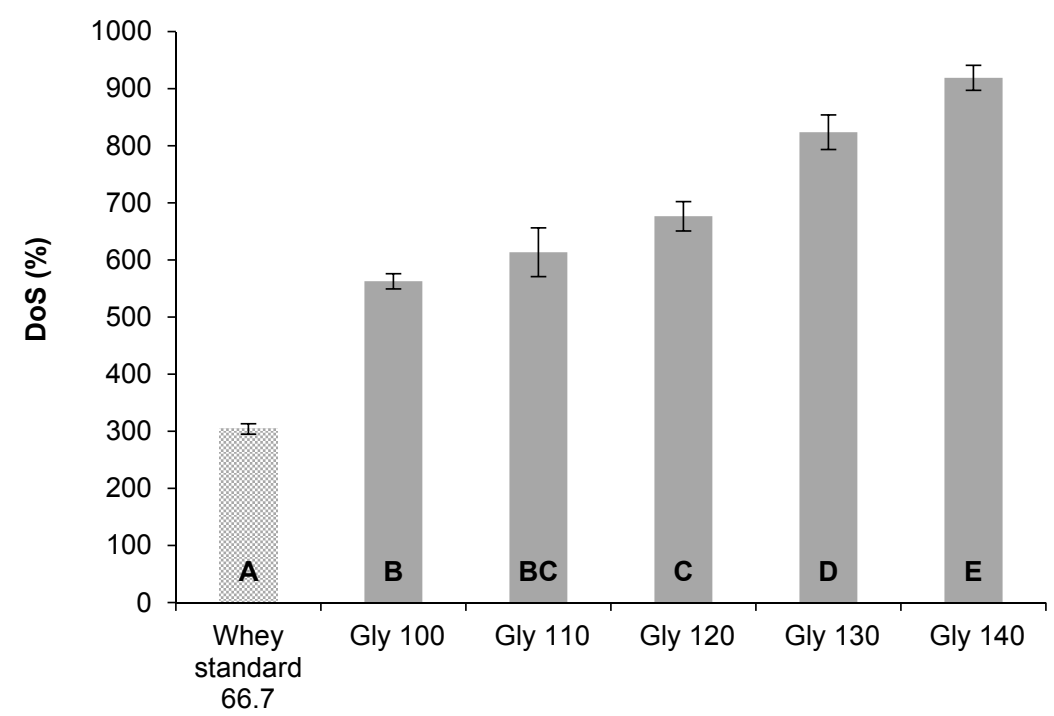

Figure 3. Influence of glycerol (Gly) concentration ( $w / w$ protein) on the degree of swelling (DoS) of PPI-based cast films and the DoS of WPI-based cast film as a reference. Columns with different letters are significantly different $(p<0.05)$. Error bars denote standard deviation.

\subsection{Mechanical Properties}

The mechanical data of all of the tested samples are listed in Table 3. Young's modulus of the whey protein standard was about twice as high as the $100 \%$ glycerol ( $w / w$ protein) sample. The values significantly $(p<0.05)$ decreased with increasing glycerol content, up to a factor of 3.5 . Schmid et al. [57] stated that primarily hydrophobic interactions and hydrogen bonds are influencing the Young's modulus of WPI-based films. The decrease in polymer stiffness with increasing glycerol concentration is therefore attributed to growing intermolecular spacing and polymer chain mobility due to an increased intermolecular interference of non-covalent interactions [22,42]. Newson et al. [9] detected a similar coherence between the stiffness of potato protein thermoformed plastic films and the glycerol concentration. The significantly higher Young's modulus of the WPI film compared to the PPI films was mainly associated to a higher number of intermolecular cross-links and non-covalent bonds. On a comparable glycerol level $(66.7 \%(w / w$ protein) $)$, the Young's modulus of PPI-based film and WPI-based standard film was a ratio of about 0.80 , as already observed for the CLD.

Table 3. Mechanical properties of WPI-based standard and PPI-based films as a function of glycerol concentration $(w / w$ protein). Significant differences between data sets are indicated by different superscript letters $(p<0.05)$.

\begin{tabular}{cccc}
\hline Sample & Young's Modulus (MPa) & Tensile Strength (MPa) & Elongation at Break *\%) \\
\hline Whey standard 66.7 & $90.8 \pm 7.2^{\mathrm{a}}$ & $4.01 \pm 0.34^{\mathrm{a}}$ & $90.0 \pm 16.2^{\mathrm{a}}$ \\
Gly 100 & $48.2^{\mathrm{a}} \pm 2.3^{\mathrm{b}}$ & $1.88 \pm 0.09^{\mathrm{b}}$ & $11.7 \pm 1.3^{\mathrm{b}}$ \\
Gly 110 & $39.7 \pm 0.2^{\mathrm{c}}$ & $1.67 \pm 0.05^{\mathrm{c}}$ & $11.4 \pm 1.5^{\mathrm{b}}$ \\
Gly 120 & $35.6 \pm 1.8^{\mathrm{d}}$ & $1.47 \pm 0.08^{\mathrm{d}}$ & $10.5 \pm 2.9^{\mathrm{b}}$ \\
Gly 130 & $20.9 \pm 2.1^{\mathrm{e}}$ & $0.93 \pm 0.09^{\mathrm{e}}$ & $9.0 \pm 4.5^{\mathrm{b}, \mathrm{c}}$ \\
Gly 140 & $13.7 \pm 2.6^{\mathrm{f}}$ & $0.64 \pm 0.07^{\mathrm{f}}$ & $6.1 \pm 1.4^{\mathrm{c}}$
\end{tabular}

* Layer thicknesses in $\mu \mathrm{m}$ of whey standard film and PPI films according to the increasing glycerol concentration: $229 \pm 26,213 \pm 32,228 \pm 21,200 \pm 41,238 \pm 44$ and $246 \pm 38$.

The tensile strength of the PPI-based films decreased significantly $(p<0.05)$, by a factor of three, with increasing glycerol content. For the WPI-based sample, the value was about twice as high as the $100 \%$ glycerol ( $w / w$ protein) sample. These results confirm the findings of various studies about edible films, which attributed the decrease in tensile strength to reduced intermolecular bonding $[20,48,56,57]$. A former study showed, among others, a decrease in the tensile strength of WPI-based films when 
disulphide bonds and non-covalent interactions were broken down using sodium sulfite $\left(\mathrm{Na}_{2} \mathrm{SO}_{3}\right)$ resp. sodium dodecyl sulfate (SDS) [57]. According to Schmid et al. [56], in cast films from denatured proteins, polypeptide molecules are forming a disordered network, with cross-links at diverse positions. The tensile strength of this network increases with increasing cross-linking density. The significantly higher tensile strength of the WPI-based film compared to the PPI films was, inter alia, therefore assigned to the absolute higher CLD. Comparing on identical glycerol content, the tensile strength of PPI-based films is about three-quarters of the WPI standard film, yet again supposed to be based on a theoretical lower CLD of the PPI-based film.

Due to high standard deviations, elongation at break was not significantly different $(p<0.05)$ for the PPI-based samples with different glycerol contents. The only exception was the film containing $140 \%$ glycerol ( $w / w$ protein) showing a significantly lower elongation at break of only $6.1 \%$. In contrast to Young's modulus and tensile strength, the results of elongation at break measurements are not standardized to film thickness. Therefore, a comparison was difficult, due to large fluctuations in film thicknesses. These results contradict the findings of previous investigations, indicating a reduction of mechanical strength as well as an increase in flexibility and extensibility with increasing glycerol content $[20,37,40,48]$. This behavior is ascribed to the reduction in intermolecular cross-links, and thus chain mobility. The whey protein standard film showed a considerably higher elongation at break, up to a factor of eight compared to the $100 \%$ glycerol ( $w / w$ protein) PPI-based specimen, indicating a significantly higher material ductility. Schmid et al. [57] clearly showed a significant decrease of elongation at break of WPI-based films when the covalent cross-linking was reduced. The authors concluded that disulphide bonds play the most important role regarding the elongation of polymer films. These results suggested the larger amount of cross-links within the whey protein polymer matrix to be responsible for the considerable higher flexibility and elongation compared to PPI-based films.

\subsection{Barrier Properties}

The water vapor transmission rate and oxygen permeability of the PPI-based samples, as well as the WPI reference sample, are shown in Table 4. They were normalized to a film thickness of $100 \mu \mathrm{m}$.

Table 4. Water vapor transmission rate and oxygen permeability of WPI standard and PPI-based films as a function of glycerol concentration $(w / w$ protein) normalized to $100-\mu \mathrm{m}$ film thickness. Significant differences are indicated by different superscript letters $(p<0.05)$.

\begin{tabular}{ccc}
\hline Sample & Oxygen Permeability $Q_{100}{ }^{*}\left(\mathbf{c m}^{\mathbf{3}} / \mathbf{m}^{\mathbf{2} \cdot \mathbf{d} \cdot \mathbf{b a r})}\right.$ & Water vapor Transmission Rate $Q_{\mathbf{1 0 0}}\left(\mathbf{g} /\left(\mathbf{m}^{\mathbf{2}} \cdot \mathbf{d}\right)\right)$ \\
\hline Whey standard 66.7 & $104.8 \pm 4.3^{\mathrm{a}}$ & $392.9 \pm 40.5^{\mathrm{a}}$ \\
Gly 100 & $230.8 \pm 7.5^{\mathrm{b}}$ & $792.7 \pm 65.3^{\mathrm{b}}$ \\
Gly 110 & $256.0 \pm 11.2^{\mathrm{b}}$ & $883.0 \pm 82.5^{\mathrm{b}, \mathrm{c}}$ \\
Gly 120 & $282.5^{\mathrm{b}} \pm 1.5^{\mathrm{b}}$ & $1055.9 \pm 172.5^{\mathrm{c}, \mathrm{d}}$ \\
Gly 130 & $339.9 \pm 35.1^{\mathrm{b}, \mathrm{c}}$ & $1237.0 \pm 48.7^{\mathrm{d}, \mathrm{e}}$ \\
Gly 140 & $396.7 \pm 20.7^{\mathrm{c}}$ & $1341.3 \pm 130.6^{\mathrm{e}}$ \\
\hline
\end{tabular}

The OP of the whey standard sample was significantly $(p<0.05)$ lower, by a factor of 2.2, than the $100 \%$ ( $w / w$ protein) PPI specimen, which showed the best oxygen barrier among the PPI-based films. Comparable studies determined similar values for the OP of WPI-based films between $82-101 \mathrm{~cm}^{3} / \mathrm{m}^{2} \cdot \mathrm{d} \cdot \mathrm{bar}[26,27]$. From $100 \%$ to $140 \%$ ( $w / w$ protein) glycerol concentration, the values increased to $397 \mathrm{~cm}^{3} / \mathrm{m}^{2} \mathrm{~d}$ bar, by a factor of 1.7. Sothornvit and Krochta [35] also determined a linear increase in the OP of $\beta$-lactoglobulin films with increasing glycerol concentration. Former studies showed a decreased OP of WPI-based films when cross-linking was increased, indicating a correlation between the OP and CLD. The authors stated that a higher CLD reduces the diffusion coefficient of the polymer, while the solubility coefficient remains constant. Since the permeation coefficient is defined as the product of diffusion coefficient and solubility coefficient, the permeability decreases [58]. This effect may also explain the significantly $(p<0.05)$ lower OP of the whey protein standard film. 
As disulphide bonds are by far the strongest intermolecular forces [6], they can be supposed to be a crucial factor for the OP. However, non-covalent hydrophobic interactions and hydrogen bonds also play a central role with regard to oxygen barrier properties, as shown in previous studies $[57,59]$.

Moreover, it was concluded that increasing intermolecular interactions reduce the distances between the protein chains, which lead to a denser and more compact polymer structure. As a consequence, permeability decreases, since less free volume impedes the oxygen molecules to pass through the polymer layer $[58,59]$.

Furthermore, the increasing moisture contents of the PPI-based films with increasing glycerol concentration, and the significantly lower value of the WPI standard $(12.9 \% \pm 1.3 \%)$, promote the passage of oxygen, since water reduces intermolecular polypeptide interactions as well. Comparing the PPI and WPI-based films on a standardized glycerol level (66.7\% ( $w / w$ protein)), a relation of about $80 \%$ would result. This indicates a correlation between the cross-linking and oxygen barrier, as this ratio was already determined for the CLD. Apart from this, further aspects such as the respective protein molecular structure and polymer orientation affecting the oxygen permeability must be considered when comparing different protein systems [59].

With increasing plasticizer content, WVTR also increased among the potato protein-based specimens, while the whey protein standard, in contrast, showed a significantly $(p<0.05)$ higher barrier, which was twice as high as the $100 \%$ PPI-based sample. The linear increase in water vapor transmission with increasing glycerol content of the PPI-based films was in agreement with further authors, who concluded that the higher WVTR were based on to the ability of glycerol to extend intermolecular spacing, and therefore promoting the dissolution of the water molecules in the matrix and facilitating to pass the layer $[20,23,41]$. Furthermore, the surface energy of the protein films decreases proportionally with increasing glycerol content due to its hygroscopic nature, leading to a hydrophilic surface, which promotes the incorporation of water molecules [42]. In regards to the linear course of the WVTR of the PPI-based films, it was suggested that the glycerol concentration and the strong hygroscopic character of both the glycerol and the polypeptide chains are the determining factors, rather than the different CLD when comparing the water barrier of these two protein systems.

\section{Conclusions}

Potato protein isolate-based biopolymers, plasticized with different polyols, were prepared. After investigating the compatibility of various plasticizers, glycerol was the only plasticizer that was able to overcome brittleness and thus produce flexible standalone films. The results of swelling tests indicated a relation between the ability of glycerol to reduce intermolecular bonding and the amount of water that is accommodated during swelling. The degree of cross-linking and cross-linking density showed an inversely proportional correlation to the degree of swelling. Comparing potato protein and whey protein-based films on the same glycerol level $(66.7 \%(w / w$ protein $))$, the cross-linking density of potato protein is approximately $80 \%$ that of whey protein. This was primarily attributed to a lower total cysteine content of PPI $(1.6 \mathrm{~g} / 16 \mathrm{~g} \cdot \mathrm{N})$ compared to WPI $(2.8 \mathrm{~g} / 16 \mathrm{~g} \cdot \mathrm{N})$, as well as the significantly lower solubility of potato protein isolate in water at $\mathrm{pH} 7.0(48.1 \%)$, which was half the value of whey protein isolate $(96 \%)$.

An increasing number of cross-links might play a central role for increasing tensile strength and Young's modulus, whereas elongation at break was unexpectedly not affected; this was a different behavior as compared to previous studies on protein-based polymers. Barrier performance also was significantly improved with increasing cross-linking, with the whey protein standard showing a considerably higher barrier against oxygen. Comparing on an identical glycerol level $(66.7 \%(w / w$ protein $))$, the performance of potato protein isolate-based films was about $80 \%$ that of whey protein isolate films regarding cross-linking, mechanical, and barrier properties, suggesting a correlation between the cross-linking density and techno-functional properties.

In summary, the determination of barrier and mechanical properties considering quantitative analysis of cross-linking in PPI-based films was carried out for the first time. These results can further 
be used to evaluate the structure of the protein network in potato protein films, and also allow a comparison with other packaging materials. Therefore, the deployment of the industrial by-product potato protein and the development of PPI-based films and coatings contribute to expanding the field of biodegradable and sustainable packaging materials as an alternative to fossil-based systems.

Acknowledgments: This study received funding from the European Union's Horizon 2020 research and innovation programme under grant agreement No. 690142. For more information, refer to http://www.agrocycle.eu/. The authors wish to acknowledge the support and assistance of all colleagues involved in this study of the Materials Development and Process Engineering Departments at Fraunhofer IVV.

Author Contributions: David Schäfer, Matthias Reinelt, and Markus Schmid conceived and designed the experiments; David Schäfer performed the experiments; David Schäfer, Matthias Reinelt, Andreas Stäbler, and Markus Schmid analyzed the data; David Schäfer wrote the paper. All authors edited the manuscript.

Conflicts of Interest: The authors declare no conflict of interest.

\section{References}

1. Tolinski, M. Plastics and Sustainability: Towards a Peaceful Coexistence between Bio-Based and Fossil Fuel-Based Plastics; John Wiley \& Sons: New York, NY, USA, 2011.

2. Coltelli, M.B.; Wild, F.; Bugnicourt, E.; Cinelli, P.; Lindner, M.; Schmid, M.; Weckel, V.; Muller, K.; Rodriguez, P.; Staebler, A.; et al. State of the art in the development and properties of protein-based films and coatings and their applicability to cellulose based products: An extensive review. Coatings 2016, 6, 1. [CrossRef]

3. Denavi, G.; Tapia-Blácido, D.R.; Añón, M.C.; Sobral, P.J.A.; Mauri, A.N.; Menegalli, F.C. Effects of drying conditions on some physical properties of soy protein films. J. Food Eng. 2009, 90, 341-349. [CrossRef]

4. Zubeldía, F.; Ansorena, M.R.; Marcovich, N.E. Wheat gluten films obtained by compression molding. Polym. Test. 2015, 43, 68-77. [CrossRef]

5. Tihminlioglu, F.; Atik, İ.D.; Özen, B. Water vapor and oxygen-barrier performance of corn-zein coated polypropylene films. J. Food Eng. 2010, 96, 342-347. [CrossRef]

6. Zink, J.; Wyrobnik, T.; Prinz, T.; Schmid, M. Physical, chemical and biochemical modifications of protein-based films and coatings: An extensive review. Int. J. Mol. Sci. 2016, 17, 1376. [CrossRef] [PubMed]

7. Waglay, A.; Karboune, S.; Alli, I. Potato protein isolates: Recovery and characterization of their properties. Food Chem. 2014, 142, 373-382. [CrossRef] [PubMed]

8. Wojnowska, I.; Poznanski, S.; Bednarski, W. Processing of potato protein concentrates and their properties. J. Food Sci. 1982, 47, 167-172. [CrossRef]

9. Newson, W.R.; Rasheed, F.; Kuktaite, R.; Hedenqvist, M.S.; Gallstedt, M.; Plivelic, T.S.; Johansson, E. Commercial potato protein concentrate as a novel source for thermoformed bio-based plastic films with unusual polymerisation and tensile properties. RSC Adv. 2015, 5, 32217-32226. [CrossRef]

10. Van Koningsveld, G.A.; Gruppen, H.; de Jongh, H.H.J.; Wijngaards, G.; van Boekel, M.A.J.S.; Walstra, P.; Voragen, A.G.J. The solubility of potato proteins from industrial potato fruit juice as influenced by $\mathrm{pH}$ and various additives. J. Sci. Food Agric. 2002, 82, 134-142. [CrossRef]

11. Strætkvern, K.O.; Schwarz, J.G. Recovery of native potato protein comparing expanded bed adsorption and ultrafiltration. Food Bioprocess Technol. 2012, 5, 1939-1949. [CrossRef]

12. Ralet, M.-C.; Guéguen, J. Fractionation of potato proteins: Solubility, thermal coagulation and emulsifying properties. LWT Food Sci. Technol. 2000, 33, 380-387. [CrossRef]

13. Løkra, S.; Helland, M.H.; Claussen, I.C.; Strætkvern, K.O.; Egelandsdal, B. Chemical characterization and functional properties of a potato protein concentrate prepared by large-scale expanded bed adsorption chromatography. LWT Food Sci. Technol. 2008, 41, 1089-1099. [CrossRef]

14. Pots, A.M. Physico-Chemical Properties and Thermal Aggregation of Patatin, the Major Potato Tuber Protein; Landbouwuniversiteit Wageningen: Wageningen, The Netherlands, 1999.

15. Van Koningsveld, G.A.; Walstra, P.; Gruppen, H.; Wijngaards, G.; van Boekel, M.A.J.S.; Voragen, A.G.J. Formation and stability of foam made with various potato protein preparations. J. Agric. Food Chem. 2002, 50, 7651-7659. [CrossRef] [PubMed]

16. Cheng, Y.; Xiong, Y.L.; Chen, J. Antioxidant and emulsifying properties of potato protein hydrolysate in soybean oil-in-water emulsions. Food Chem. 2010, 120, 101-108. [CrossRef] 
17. Pouvreau, L.; Gruppen, H.; Piersma, S.R.; van den Broek, L.A.M.; van Koningsveld, G.A.; Voragen, A.G.J. Relative abundance and inhibitory distribution of protease inhibitors in potato juice from cv. Elkana. J. Agric. Food Chem. 2001, 49, 2864-2874. [CrossRef] [PubMed]

18. Van Koningsveld, G.A.; Gruppen, H.; de Jongh, H.H.; Wijngaards, G.; van Boekel, M.A.; Walstra, P.; Voragen, A.G. Effects of $\mathrm{pH}$ and heat treatments on the structure and solubility of potato proteins in different preparations. J. Agric. Food Chem. 2001, 49, 4889-4897. [CrossRef] [PubMed]

19. Hammann, F.; Schmid, M. Determination and quantification of molecular interactions in protein films: A review. Materials 2014, 7, 7975-7996. [CrossRef] [PubMed]

20. Shaw, N.B.; Monahan, F.J.; O'Riordan, E.D.; O'Sullivan, M. Physical properties of wpi films plasticized with glycerol, xylitol, or sorbitol. J. Food Sci. 2002, 67, 164-167. [CrossRef]

21. Schmid, M.; Dallmann, K.; Bugnicourt, E.; Cordoni, D.; Wild, F.; Lazzeri, A.; Noller, K. Properties of whey-protein-coated films and laminates as novel recyclable food packaging materials with excellent barrier properties. Int. J. Polym. Sci. 2012, 2012, 562381. [CrossRef]

22. Schmid, M. Properties of cast films made from different ratios of whey protein isolate, hydrolysed whey protein isolate and glycerol. Materials 2013, 6, 3254-3269. [CrossRef] [PubMed]

23. McHugh, T.H.; Aujard, J.F.; Krochta, J.M. Plasticized whey-protein edible films-Water vapor permeability properties. J. Food Sci. 1994, 59, 416-419. [CrossRef]

24. AOCS BA 11-65 Nitrogen Solubility Index (NSI); American Oil Chemists' Society: Urbana, IL, USA, 1993.

25. AACC Method 46-23 Nitrogen Solubility Index. Approved methods of the American Association of Cereal Chemists (AACC); American Association of Cereal Chemists: St. Paul, MN, USA, 1983.

26. Schmid, M.; Pröls, S.; Kainz, D.M.; Hammann, F.; Stäbler, A. Impact of hydrolyzed whey protein on the molecular interactions and cross-linking density in whey protein isolate-based films. Int. J. Polym. Sci. 2016, 2016, 3723758. [CrossRef]

27. Schmid, M.; Pröls, S.; Kainz, D.M.; Hammann, F.; Grupa, U. Effect of thermally induced denaturation on molecular interaction-response relationships of whey protein isolate based films and coatings. Prog. Org. Coat. 2017, 104, 161-172. [CrossRef]

28. DIN EN ISO 175:2010-10 Kunststoffe-Prüfverfahren zur Bestimmung des Verhaltens gegen flüssige Chemikalien; Deutsches Institut für Normung e.V.: Berlin, Germany, 2010. (In German)

29. Pęksa, A.; Miedzianka, J. Amino acid composition of enzymatically hydrolysed potato protein preparations. Czech J. Food Sci. 2014, 32, 265-272.

30. Ahmed, K.; Nizami, S.S.; Raza, N.Z.; Mahmood, K. Mechanical, swelling, and thermal aging properties of marble sludge-natural rubber composites. Int. J. Ind. Chem. 2012, 3, 21. [CrossRef]

31. DIN EN ISO 527-1 Kunststoffe-Bestimmung der Zugeigenschaften; Deutsches Institut für Normung e.V.: Berlin, Germany, 2012. (In German)

32. DIN 53122-1 Bestimmung der Wasserdampfdurchlässigkeit. Teil 1: Gravimetrisches Verfahren; Deutsches Institut für Normung e.V.: Berlin, Germany, 2001. (In German)

33. DIN 53380-3 Bestimmung der Gasdurchlässigkeit. Teil 3: Sauerstoffspezifisches Trägergas-Verfahren zur Messung an Kunststoff-Folien und Kunststoff-Formteilen; Deutsches Institut für Normung e.V.: Berlin, Germany, 1998. (In German)

34. Ronniger, C.U. Taschenbuch der Statistischen Qualitäts-und Zuverlässigkeitsmethoden: Die Wichtigsten Methoden und Verfahren für Die Praxis; CRGRAPH: Starnberg, Germany, 2013. (In German)

35. Sothornvit, R.; Krochta, J. Plasticizer effect on oxygen permeability of $\beta$-lactoglobulin films. J. Agric. Food Chem. 2000, 48, 6298-6302. [CrossRef] [PubMed]

36. Verbeek, C.J.R.; van den Berg, L.E. Extrusion processing and properties of protein-based thermoplastics. Macromol. Mater. Eng. 2010, 295, 10-21. [CrossRef]

37. Sothornvit, R.; Krochta, J.M. Plasticizer effect on mechanical properties of $\beta$-lactoglobulin films. J. Food Eng. 2001, 50, 149-155. [CrossRef]

38. Griffin, W.; Lynch, M. Polyhydric alcohols. In Handbook of Food Additives, 2nd ed.; Furia, T., Ed.; CRC Press: Cleveland, OH, USA, 1980; Volume 2, pp. 431-455.

39. Cuq, B.; Gontard, N.; Cuq, J.-L.; Guilbert, S. Selected functional properties of fish myofibrillar protein-based films as affected by hydrophilic plasticizers. J. Agric. Food Chem. 1997, 45, 622-626. [CrossRef]

40. Jangchud, A.; Chinnan, M.S. Properties of peanut protein film: Sorption isotherm and plasticizer effect. LWT Food Sci. Technol. 1999, 32, 89-94. [CrossRef] 
41. Gontard, N.; Guilbert, S.; Cuq, J.-L. Water and glycerol as plasticizers affect mechanical and water vapor barrier properties of an edible wheat gluten film. J. Food Sci. 1993, 58, 206-211. [CrossRef]

42. Ramos, Ó.L.; Reinas, I.; Silva, S.I.; Fernandes, J.C.; Cerqueira, M.A.; Pereira, R.N.; Vicente, A.A.; Pocas, M.F.; Pintado, M.E.; Malcata, F.X. Effect of whey protein purity and glycerol content upon physical properties of edible films manufactured therefrom. Food Hydrocoll. 2013, 30, 110-122. [CrossRef]

43. CHERIC. Pure Component Properties. Available online: https://www.cheric.org/research/kdb/hcprop/ cmpsrch.php (accessed on 10 December 2017).

44. Orliac, O.; Rouilly, A.; Silvestre, F.; Rigal, L. Effects of various plasticizers on the mechanical properties, water resistance and aging of thermo-moulded films made from sunflower proteins. Ind. Crop. Prod. 2003, 18, 91-100. [CrossRef]

45. Viroben, G.; Barbot, J.; Mouloungui, Z.; Guéguen, J. Preparation and characterization of films from pea protein. J. Agric. Food Chem. 2000, 48, 1064-1069. [CrossRef] [PubMed]

46. Vanin, F.M.; Sobral, P.J.A.; Menegalli, F.C.; Carvalho, R.A.; Habitante, A.M.Q.B. Effects of plasticizers and their concentrations on thermal and functional properties of gelatin-based films. Food Hydrocoll. 2005, 19, 899-907. [CrossRef]

47. Donhowe, I.G.; Fennema, O. The effects of plasticizers on crystallinity, permeability, and mechanical properties of methylcellulose films. J. Food Process. Preserv. 1993, 17, 247-257. [CrossRef]

48. Nemet, N.T.; Šošo, V.M.; Lazić, V.L. Effect of glycerol content and pH value of film-forming solution on the functional properties of protein-based edible films. Acta Period. Technol. 2010, 57-67. [CrossRef]

49. De Wit, J. Lehrbuch der Molke und Molkenerzeugnisse; European Whey Products Association: Brüssel, Belgium, 2001.

50. Creusot, N.; Wierenga, P.A.; Laus, M.C.; Giuseppin, M.L.F.; Gruppen, H. Rheological properties of patatin gels compared with $\beta$-lactoglobulin, ovalbumin, and glycinin. J. Sci. Food Agric. 2011, 91, 253-261. [CrossRef] [PubMed]

51. Vikelouda, M.; Kiosseoglou, V. The use of carboxymethylcellulose to recover potato proteins and control their functional properties. Food Hydrocoll. 2004, 18, 21-27. [CrossRef]

52. Montalvo-Paquini, C.; Rangel-Marron, M.; Palou, E.; Lopez-Malo, A. Effect of pH on physical properties of edible films from faba bean protein. Recent Adv. Chem. Eng. Biochem. Comput. Chem. 2013, 29-34.

53. Venugopal, V. Marine Products for Healthcare: Functional and Bioactive Nutraceutical Compounds from the Ocean; CRC Press: Boca Raton, FL, USA, 2008.

54. Peppas, N.A.; Ottenbrite, R.M.; Park, K.; Okano, T. Biomedical Applications of Hydrogels Handbook; Springer Science \& Business Media: New York, NY, USA, 2010.

55. Schmidt, M.; Rodler, N.; Miesbauer, O.; Rojahn, M.; Vogel, T.; Dörfler, R.; Kucukpinar, E.; Langowski, H.-C. Adhesion and barrier performance of novel barrier adhesives used in multilayered high-barrier laminates. J. Adhes. Sci. Technol. 2012, 26, 2405-2436. [CrossRef]

56. Schmid, M.; Prinz, T.K.; Müller, K.; Haas, A. UV radiation induced cross-linking of whey protein isolate-based films. Int. J. Polym. Sci. 2017, 2017, 1846031. [CrossRef]

57. Schmid, M.; Prinz, T.K.; Stäbler, A.; Sängerlaub, S. Effect of sodium sulfite, sodium dodecyl sulfate, and urea on the molecular interactions and properties of whey protein isolate-based films. Front. Chem. 2016, 4, 49. [CrossRef] [PubMed]

58. Schmid, M.; Sängerlaub, S.; Wege, L.; Stäbler, A. Properties of transglutaminase crosslinked whey protein isolate coatings and cast films. Packag. Technol. Sci. 2014, 27, 799-817. [CrossRef]

59. Schmid, M.; Reichert, K.; Hammann, F.; Stäbler, A. Storage time-dependent alteration of molecular interaction-property relationships of whey protein isolate-based films and coatings. J. Mater. Sci. 2015, 50, 4396-4404. [CrossRef]

(C) 2018 by the authors. Licensee MDPI, Basel, Switzerland. This article is an open access article distributed under the terms and conditions of the Creative Commons Attribution (CC BY) license (http://creativecommons.org/licenses/by/4.0/). 